\title{
Differences in eggshell pigmentation pattern between Common Moorhen Gallinula chloropus and Eurasian Coot Fulica atra eggs
}

\author{
Valentin Adrian KIss ${ }^{*, 1,2}$, Liviu Răzvan PRIPON ${ }^{3}$ \& Attila MARTON ${ }^{4,5}$
}

Received: April 27, 2020 - Revised May 11, 20202 -Accepted: May 12, 2020

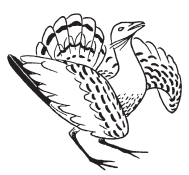

Kiss, V. A., Pripon, L., R. \& Marton, A. 2020. Differences in eggshell pigmentation pattern between Common Moorhen Gallinula chloropus and Eurasian Coot Fulica atra eggs. - Ornis Hungarica 28(1): 176-180. DOI: 10.2478/orhu-2020-0011 the nests of conspecifics or closely related species. The Common Moorhen Gallinula chloropus is a well-known facultative brood parasite that nests in wetlands, which are utilised also by a wide range of waterfowl, including the Eurasian Coot Fulica atra. The two species breed in similar habitats and have a similar egg pigmentation pattern; thus, the Coot can be a suitable host of brood-parasitic Moorhen. To study whether there is any discernible difference between the spotting pattern of Coot and Moorhen eggs, we compared the density of different sized spots on eggs of the two species. Our results show that Coot eggs have a significantly higher density of small speckles then Moorhen eggs, while the latter species has eggs with more conspicuous larger spots. Therefore, Coots can possibly rely on these differences in eggshell pattern to recognize and eject the brood parasitic Moorhen eggs.

Keywords: aquatic birds, interspecific brood parasitism, egg morphology, Rallidae

Összefoglalás A fakultatív költésparazita madárfajok növelhetik szaporodási sikerüket azáltal, hogy tojásaik egy részét azonos vagy közelrokon fajok fészkébe tojják. A vizes élőhelyeken fészkelő vízityúk (Gallinula chloropus) egy közismert fakultatív költésparazita, amely néha a szárcsát (Fulica atra) is parazitálja. A két faj hasonló élöhelyen költ, és hasonló tojásmintázattal rendelkezik, így a szárcsa kézenfekvő gazdafaj lehet a vízityúk számára. Összehasonlítottuk a két faj tojásain található, különböző méretű foltok gyakoriságát azért, hogy megvizsgáljuk, van-e olyan észlelhetö különbség a tojásaik mintázata között, amely révén a szárcsa felismerheti a fészekidegen tojásokat. Eredményeink azt mutatják, hogy a szárcsa tojásai jelentősen sủrübben szeplözöttek a vízityúkénál, míg utóbbi tojásain, gyakrabban előfordulnak szembetűnőbb, nagyobb foltok. A tojások mintázatbeli különbsége lehetővé teheti a szárcsa számára, hogy felismerje a vízityúk tojásait, és elkerülje a költésparazitizmussal járó költségeket.

Kulcsszavak: vízi madarak, fajok közötti fészekparazitizmus, tojás színezet, guvatfélék

${ }^{1}$ Babeș-Bolyai University, Faculty of Biology and Geology; 400006 Cluj-Napoca, Str. Clinicilor nr 5-7., Romania,e-mail: kissvalentinadrian@gmail.com

${ }^{2}$ Babeș-Bolyai University, Student College for Advanced Performance Studies; 400376 Cluj-Napoca, Str. Pandurilor $n$ r 7., Romania

${ }^{3}$ Babeș-Bolyai University, Faculty of History and Philosophy; 400084 Cluj-Napoca, Str. Mihail Kogălniceanu nr 1., Romania

${ }^{4}$ Department of Evolutionary Zoology and Human Biology, University of Debrecen, 4032 Debrecen, Egyetem tér 1., Hungary

${ }^{5}$ Juhász-Nagy Pál Doctoral School, University of Debrecen, 4032 Debrecen, Egyetem tér 1., Hungary

* corresponding author 


\section{Introduction}

Brood parasitism is a reproductive strategy found across a wide range of avian taxa (Haraszthy 2019a, b), in which females lay their eggs in the nest of conspecific or heterospecific hosts, with the aim of increasing their own reproductive output on the expense of the hosts' parental care directed towards the host's own brood (Davies 2000). While only $1 \%$ of all avian taxa are obligate brood parasites (i.e. rely solely on the parental care of heterospecific hosts), conspecific brood parasitism is a facultative strategy, and it is more common in precocial species (e.g. around $60 \%$ of all Anatidae species, Yom-Tov \& Geffen 2018). Common Moorhens Gallinula chloropus (Moorhen hereafter) exhibit a highly diverse breeding strategy, ranging from monogamy to polygamy and polygyny, but are also notoriously brood parasitic (Gibbons 1986). Moreover, besides eggs dumped in the nests of conspecifics, Moorhen eggs were found within the clutches of Little Bittern Ixobrichus minutus, Eurasian Coot Fulica atra (Coot from hereafter), Grey Partridge Perdix perdix, Little Grebe Tachybaptus ruficollis, Black-headed Gull Chroicocephalus ridibundus and Ferruginous Duck Aythia nyroca (Engler 1983, David et al. 2005, Meniaia et al. 2014, Haraszthy 2018).

The nestlings of precocial species do not rely as heavily on the care of their parents (or foster parents) as altricial nestlings do, however, increased number of eggs in the nest might lead to nest destruction (Wang et al. 2013) or lower fledgling success (Lyon 1993, 2003). For example, in the Moorhen population studied by Gibbons (1986), the mean number of nestlings successfully reared from nests containing eggs from only one female was 1.70 , while only 1.20 nestlings fledged from the nests containing the eggs of multiple females. Therefore, hosts are expected to evolve defences to minimize the occurrence and negative effect of brood parasitism, by recognizing the parasites as enemies, or by recognizing and rejecting brood parasitic eggs (Davies 2000).

After finding a seemingly rejected Moorhen egg next to a clutch of Coot eggs, we decided to investigate whether the differences in eggshell pigmentation may constitute reliable cues for the Coot in the recognition and rejection of Moorhen eggs. We hypothesise that there are some subtle differences in the eggshell pigmentation that enable Coots to recognize foreign eggs, thus evading brood parasitism. Coot and Moorhen eggs are fairly similar in size and shape, and have fine speckles and brownish blotches of various sizes on a white-ivory background. We predict that the density of fine speckles is higher on Coot eggs, while in contrast, the density of larger blotches is higher on Moorhen eggs.

\section{Materials and methods}

The Eurasian Coot is one of the most abundant species at our study site Câmpeneşti fishponds, Romania $\left(46^{\circ} 50^{\prime} 35.7^{\prime \prime} \mathrm{N} 23^{\circ} 42^{\prime} 23.1^{\prime \prime} \mathrm{E}\right)$, where it reproduces in large numbers despite the intense human activity around the fishpond, and forms relatively abundant flocks in winter (Kiss \& Pripon 2019). Here, we found a seemingly rejected Moorhen egg next to a Coot nest containing 8 eggs in 2018. In order to quantify the differences in eggshell 
pigmentation, we conducted spot counts based on spot size, on Coot eggs from different nests from our study site $(n=5)$ and Moorhen eggs $(n=5)$. To have an identical sample size between the two species, besides the Moorhen egg found next to the Coot nest in 2018, we sampled four locally collected Moorhen eggs in the oological collection of Zoological Museum of the Babeș-Bolyai University.

We classified the markings on the eggs based on the diameter of the spots on the eggshell, as follows: "speckles" $(<0.5 \mathrm{~mm})$, "small spots" $(0.5-1 \mathrm{~mm})$, "large spots" $(1-3 \mathrm{~mm})$ and "blotches" ( $>3 \mathrm{~mm})$. We photographed 6 squares on each egg through a handheld magnifier glass ( $5 \times$ magnification) and direct visually counted the spots of different sizes. Thus, we evaluated the number of spots on 30 squares collected from Coot eggs and 30 squares collected from Moorhen eggs, and calculated their average number and relative frequency. Large spots and blotches scarcer and more dispersed then speckles and small spots, therefore are better evaluated by relative frequency within the randomly selected squares. Both evaluations reflect the density of spots on the eggshell surface.

We performed One-way ANOVA analysis using PAST programme in order to test difference between the egg markings of the two species.

\section{Results}

Although Coot and Moorhen eggs have a highly similar eggshell pigmentation pattern, we found marked differences in the abundance and relative frequency of different sized spots between the eggs of the two species (Table 1).

Coot eggs had on average more speckles then Moorhen eggs $(F=297.20, d f=33.54, P<$ $0.001)$, while Moorhen eggs had a higher abundance of small spots $(F=10.72, d f=46.31$, $P=0.002)$ and blotches $(F=13.42, d f=33.83, P<0.001)$. We found no significant difference in the abundance of large spots (i.e. spots of $1-3 \mathrm{~mm}$ diameter) between the two spe$\operatorname{cies}(F=2.06, d f=56.36, P=0.157)$.

Table 1. Minimum, maximum, mean $( \pm S D)$ number of each type of spots per evaluated square (25 $\mathrm{mm}^{2}$ ), and the relative frequency ( $\left.F \%\right)$ of each type of spots on Coot and Moorhen eggs

1. táblázat Különböző méretű foltok relatív gyakorisága ( $F \%)$, illetve minimum, maximum és átlagos $( \pm S D)$ száma $25 \mathrm{~mm}^{2}$-es mintavételezési négyzetekben, szárcsa és vízityúk tojásokon

\begin{tabular}{|l|c|c|c|c|c|c|c|c|}
\hline & \multicolumn{2}{|c|}{ Speckles } & \multicolumn{2}{c|}{ Small spots } & \multicolumn{2}{c|}{ Large spots } & \multicolumn{2}{c|}{ Blotches } \\
\cline { 2 - 9 } & Coot & Moorhen & Coot & Moorhen & Coot & Moorhen & Coot & Moorhen \\
\hline Min & 72 & 12 & 0 & 0 & 0 & 0 & 0 & 0 \\
\hline Max & 185 & 40 & 4 & 9 & 4 & 2 & 1 & 3 \\
\hline Mean & 111.06 & 22.40 & 1.66 & 3.40 & 0.53 & 0.86 & 0.10 & 0.83 \\
\pm SD & \pm 27.12 & \pm 7.61 & \pm 1.44 & \pm 2.51 & \pm 0.97 & \pm 0.81 & \pm 0.30 & \pm 1.05 \\
\hline F\% & $100 \%$ & $100 \%$ & $60 \%$ & $90 \%$ & $30 \%$ & $60 \%$ & $10 \%$ & $46 \%$ \\
\hline
\end{tabular}




\section{Discussion}

The recognition of brood parasitic eggs by hosts, based on the eggshell markings is a widespread and well-studied host defence (Davies 2000). Host that fail to recognize foreign eggs and act on it accordingly, are compelled to invest parental care in non-kin offspring at the detriment of their own offspring (Lyon 2003, Wang 2013).

We found marked differences between the eggshell pattern of the facultative brood parasitic Moorhen and its occasional host, the Eurasian Coot. Therefore, our results provide evidence that Coots could rely on the differences in eggshell pigmentation to recognize foreign eggs and evade the costs of brood parasitism. The recognition of own eggs might be particularly important in this species, because besides facing the odds of the occasional interspecific brood parasitism of the Moorhen, the Coot is also known to utilize this alternative reproductive strategy as a facultative intra- and conspecific brood parasite (Samraoui \& Samraoui 2007, Haraszthy 2018).

The American Coot Fulica americana is known to count its eggs and to recognize if there are extra eggs in its clutch (Lyon 2003), however, it is not known if this frontline defence is shared with its sister taxa, the Eurasian Coot.

If the Eurasian Coot is capable of true egg recognition (sensu Lyon 2007), the occurrence of intraspecific or conspecific brood parasitism might be higher than reported in previous studies, since hosts might immediately recognize and remove foreign eggs from the clutch. Further studies are needed to assess the extent and costs of Moorhen brood parasitism on Coots, alongside an experimental framework for testing the underlying mechanisms of brood parasitic egg recognition by Coots. However, since a closely related species showed marked egg recognition abilities during experimental egg-swaps (Lyon 1993, 2003, 2007), it is worth mentioning that for such experiments freshly collected Moorhen eggs are needed, to exclude the confounding effect of other egg recognition cues (e.g. surface ruggedness of clay eggs, low weight of eggs from oological collections etc.).

We conclude that the eggshell pigmentation patterns can serve as reliable cues for the Coot to recognize its own eggs and spot foreign eggs within its clutch, thus evading the costs posed by brood parasitism.

\section{Acknowledgements}

We express our gratitude towards Gergely Osváth for giving us the opportunity to study the eggs belonging to the ornithological collection of Zoological Museum of the Babeș-Bolyai University, Mihai Pop for his help in the field work and Horea Olosutean for his statistical guidance. We wish to thank László Haraszthy for his constructive comments during the review process of the manuscript. This research was funded by Milvus Group Association's Scholarship Grant and Babeș-Bolyai University through the Special research scholarship, both awarded to Valentin Adrian Kiss. 


\section{References}

Davies, N. B. 2000. Cuckoos, Cowbirds and Other Cheats. - Poyser Publishing

David, A., Vass, C. \& Coroiu, I. 2005. A new case of interspecific brood parasitism in Common Moorhen Gallinula chloropus. - Avocetta 29: 33-36.

Engler, H. 1983. Die Teichralle [Common Moorhen]. - Die Neue Brehm-Bücherei 536., A. Ziemsen Verlag, Wittenberg, Lutherstadt (in German)

Gibbons, D. W. 1986. Brood parasitism and cooperative nesting in the Moorhen, Gallinula chloropus. - Behavioural Ecology and Sociobiology 19: 221-232. DOI: 10.1007/BF00300863

Haraszthy, L. 2018. Intra- and interspecific nest parasitism of Common Moorhen (review of cases and new data). - Ornis Hungarica 26(1): 95-101. DOI: 10.1515/orhu-2018-0007

Haraszthy, L. 2019a New species on the list of species with intraspecific nest parasitism. - Ornis Hungarica 27(1): 166-206. DOI: 10.2478/orhu-2019-0010

Haraszthy, L. 2019b Cases of occasional interspecific brood parasitism and egg dumping in Hungary. - Ornis Hungarica 27(2): 115-141. DOI: 10.2478/orhu-2019-0020

Kiss, V. A. \& Pripon, L. R. 2019. A reevaluation of the avifauna from Câmpenești fishing complex (Cluj County, Romania) in the context of high human impact. - Brukenthal Acta Musei XIV. 3.

Lyon, B. E. 1993. Conspecific brood parasitism as a flexible female reproductive tactic in American Coots. - Animal Behaviour 46: 911-928. DOI: 10.1006/anbe.1993.1273

Lyon, B. E. 2003. Egg recognition and counting reduce costs of avian conspecific brood parasitism. - Nature 422: 495-499. DOI: 10.1038/nature01505

Lyon, B. E. 2007. Mechanism of egg recognition in defenses against conspecific brood parasitism: American coots (Fulica americana) know their own eggs. - Behavioral Ecology and Sociobiology (61): 455-463. DOI: 10.1007/s00265-006-0273-2

Meniaia, Z., Samraoui, F., Alfarhan, A. H. \& Samraoui, B. 2014. Nest-site selection, breeding success and brood parasitism in the Common Moorhen Gallinula chloropus in Algeria. - Zoology and Ecology 24(4): 305-313. DOI: $10.1080 / 21658005.2014 .959281$

Samraoui, F. \& Samraoui, B. 2007. The reproductive ecology of the Common Coot Fulica atra in the Hauts Plateaux, Northeast Algeria. - Waterbirds 30(1): 133-139. DOI: 10.1675/1524-4695(2007)030[0133:TREOTC]2.0.CO;2

Wang, L., Canchao, Y., Hsu, Y. C., Antonov, A., Moksnes, A., Røskaft, E., Liang, W. \& Stokke, B. G. 2013. Increase of clutch size triggers clutch destruction behaviour in Common Moorhens Gallinula chloropus during the incubation period. - Behaviour 150(2): 215-223. DOI: 10.1163/1568539X-00003046

Yom-Tov, Y. \& Geffen, E. 2018. Conspecific brood parasitism among birds: the effect of phylogeny, mode of reproduction and geographic distribution. - In: Soler, M. (ed.) Avian Brood Parasitism: Behaviour, Ecology, Evolution and Coevolution. - Springer International Publishing. DOI: 10.1007/978-3-319-73138-4_5

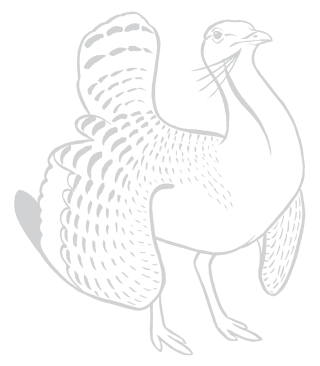

